\title{
Effect of Different Intensity Outdoor Tennis Training on Cardiac Load
}

\author{
Hao Sen ${ }^{1}$, Hao Mengyuan ${ }^{2}$ \\ ${ }^{1}$ Nanyang Agricultural Vocational College, Henan, China \\ ${ }^{2} \mathrm{PhD}$ candidate at Adamson University, Manila,Philippines
}

\begin{abstract}
:
Starting from the outdoor tennis competition, this paper studies the load characteristics of tennis competition through the experimental test of outdoor tennis players. This paper mainly adopts four research methods: literature, experimental test, mathematical statistics and logical analysis. This paper analyzes the load characteristics of outdoor tennis players in singles through experiments on the characteristics of competition time, the changes of center rate in the process of competition and the changes of creatine kinase, blood urea and urinary protein before and after competition. The results showed that the content of creatine kinase in blood increased significantly and the protein in urine increased significantly. This shows that outdoor tennis competition is more intense. The increase of blood urea after competition shows that there is a certain load in outdoor tennis competition, but the load is relatively small. The small load is mainly due to the short time of outdoor tennis competition, so the content of blood urea will not increase significantly.
\end{abstract}

Keywords: Outdoor, Forest, Tennis Competition, Competition Load Characteristics.

\section{INTRODUCTION}

Modern tennis was born in England. Now, tennis is developing rapidly, the competition for the field is more intense and full of gunpowder. With the continuous emergence of tennis competitions and excellent tennis players, as well as the interesting, competitive and entertaining characteristics of tennis itself, tennis has been widely promoted all over the world.

Since Li Ting and sun Tiantian won the women's Doubles Championship in 2004 Athens Olympic Games. Zheng Jie and Yan Zi won the doubles championship at the Australian Open in 2006, and Peng Shuai of China ranked first in the women's doubles world in 2014, marking a major breakthrough in doubles in China's women's tennis [1-2]. Li Na won the French Open Championship in 2011 and the Australian Open Championship in 2014 [3]. Li Na's ranking also reached the highest second place in the world, marking a major breakthrough in singles for 
Article History: Received: 28 October 2021 Revised: 05 December 2021 Accepted: 10 January 2022 Publication: 28 February 2022

Chinese women's tennis players. With the gradual increase of tennis competitions held and broadcast in China, many people have a strong interest in tennis, and their enthusiasm for learning tennis is higher and higher [4-5]. Under the influence of Shanghai Masters, the atmosphere of learning tennis in China is becoming stronger and stronger [6]. In recent years, many tennis clubs have sprung up in the society, and some professional tennis schools have begun to be established. More and more people are learning tennis. Most colleges and universities have built tennis courts to varying degrees, set up tennis classes, and have their own tennis training teams. There are more and more exchanges of tennis competitions among colleges and universities, the competitive level is higher and higher, and the competition is more and more intense. Therefore, it is very necessary and urgent to study and analyze college tennis players.

\section{RESEARCH OBJECTS AND METHODS}

\section{Research object}

Load characteristics of students' singles competition in tennis special class (school team members) of sports training major in Shanghai Institute of physical education [7].

2.Research method

Generally speaking, the selection of physiological and biochemical indexes is different for different test purposes. At present, according to the characteristics of physiological and biochemical indexes, the biochemical evaluation of exercise load in China is often tested by the following combinations (Table 1).

TABLE I. Confrontation time per minute and baseline confrontation ratio of singles in the four Grand Slams from 1997 to 1999

\begin{tabular}{|c|c|c|c|c|c|c|}
\hline & Female & Man & Aowang & $\begin{array}{c}\text { The long arm of } \\
\text { the law }\end{array}$ & Wenwang & U.S. Open \\
\hline $\begin{array}{c}\text { CONFRONTATION } \\
\text { TIME PER } \\
\text { MINUTE (S) }\end{array}$ & $7.1 \pm 2.0$ & $5.2 \pm 1.8$ & $6.3 \pm 1.8$ & $7.7 \pm 1.7$ & $4.3 \pm 1.6$ & $5.8 \pm 1.9$ \\
\hline $\begin{array}{c}\text { BOTTOM LINE } \\
\text { CONFRONTATION } \\
\text { RATIO (\%) }\end{array}$ & $52.8 \pm 12.4$ & $28.6 \pm 19$ & $46.6 \pm 12.5$ & $51.9 \pm 14.2$ & $19.7 \pm 19.4$ & $35.4 \pm 19.5$ \\
\hline
\end{tabular}

Select the students of tennis special class (school team members) majoring in sports training of Shanghai Institute of physical education to pass the ranking competition in the team. Choose 6 boys from 1-6 and 4 girls from 1-4. The experimental test shall be conducted according to the 
Article History: Received: 28 October 2021 Revised: 05 December 2021 Accepted: 10 January 2022 Publication: 28 February 2022

first and second matches, the third against the fourth, and the fifth against the sixth. Boys are numbered 1-6 and girls are numbered 7-10. After inquiry and physical examination, all athletes were in good health and had no genetic history. The measurement of heart rate includes: Athletes' quiet heart rate and pre competition heart rate; The heart rate at the end of each minute of the whole game (in tennis, the heart rate value of the athlete at the end of each minute), the average heart rate of the whole game and the maximum heart rate of the whole game. Heart rate chart for the whole game. Changes of serum creatine kinase, blood urea and urinary protein before and after tennis match [8-9].

According to the competition system and rules used in the 2013 College Tennis League, group $\mathrm{B}$ and group $\mathrm{C}$ adopt the system of grabbing 8 games and winning a draw, that is, one player wins 8 games first; However, when the score is 7-7, it takes a net win of 2 games (i.e. 9-7) to win; When the score reached 8-8, a seven game showdown was held. The competition adopts one-man referee system, and table 2 is the competition table.

TABLE II. Match table

\begin{tabular}{|c|c|c|}
\hline \multirow{2}{*}{ MATCH } & & $\begin{array}{c}\text { ATHLETES FROM } \\
\text { BOTH SIDES OF THE } \\
\text { COMPETITION }\end{array}$ \\
\hline \multirow{2}{*}{$\begin{array}{c}\text { MEN'S SINGLES } \\
\text { COMPETITION }\end{array}$} & One & $3-1$ \\
\cline { 2 - 3 } & Two & $2-5$ \\
\cline { 2 - 3 } & Three & $4-6$ \\
\hline $\begin{array}{c}\text { WOMEN'S SINGLES } \\
\text { COMPETITION }\end{array}$ & Four & $7-10$ \\
\cline { 2 - 3 } & Five & $8-9$ \\
\hline
\end{tabular}

In order to verify the objectivity and reliability of the test, a pre experiment is required. Repeat the measurement of the test index. In order to reduce the experimental interference factors, the athletes' diet for one week is controlled to avoid eating high protein food the week before the test. Two days before the test, the athletes are reminded to pay attention to rest and avoid physical fatigue, which will affect the play of the competition and the results of the experiment [10]. In order to reduce the error of experimental test, this study conducted two experimental tests on athletes with an interval of 2 weeks. Through the t-test analysis of the two experimental results, it is concluded whether there is significant difference between the two experimental results.

The original data of the paper is stored and established by Excel software, and the mathematical statistics is processed and analyzed by SPSS17.0 software package. The measured data are expressed by mean and standard deviation, and the method of sports statistics is used to 
Article History: Received: 28 October 2021 Revised: 05 December 2021 Accepted: 10 January 2022 Publication: 28 February 2022

test the difference between the first experimental test and the second experimental test ( $t$ test). The relevant data obtained are made into charts or tables to analyze the load characteristics of college tennis players in tennis singles competition.

Through research, this paper analyzes the changes of physiological and biochemical indexes of the experimental subjects before and after the game, and analyzes the overall change trend of college tennis players before and after the game, so as to find out the particularity of college tennis game. Through the comprehensive analysis of various indexes, this paper makes a comprehensive evaluation on the changes of physiological and biochemical indexes in college students' tennis singles competition. At the same time, combined with the characteristics of competition time, this paper makes a comprehensive analysis on the singles competition load of college tennis players.

\section{RESULTS AND ANALYSIS}

T-test uses t-distribution theory to infer the probability of difference, so as to determine whether the difference between the two averages is significant. The data of the two experiments were tested by paired sample t-test to determine whether there was a significant difference between the first experimental test and the second experimental test. More scientific analysis of the data.

For the results of t-test of two experimental data, compared with the results of the first experiment and the second experiment, $\mathrm{P}$ values are greater than 0.05 . If $\mathrm{P}>0.05$, there is no significant difference; If $\mathrm{P}<0.05$, there was significant difference; If $\mathrm{P}<0.01$, there was a highly significant difference. Therefore, there is no difference between the two tests. The experimental data are true, reliable and objective. Therefore, this study uses the data of the second experimental test for analysis and research.

From table 3, we can see that the number of innings played in a game is between 10 and 14 . The third group has the most games, playing 14 games, and the second and fourth groups have the least, both of which are 10 games.

\section{TABLE III. Competition results}

\begin{tabular}{|c|c|}
\hline MATCH & SCORE \\
\hline ONE & $8: 3$ \\
\hline TWO & $8: 2$ \\
\hline THREE & $8: 6$ \\
\hline FOUR & $8: 2$ \\
\hline FIVE & $8: 4$ \\
\hline
\end{tabular}


Article History: Received: 28 October 2021 Revised: 05 December 2021 Accepted: 10 January 2022 Publication: 28 February 2022

From table 4, we can see that the longest competition time is 33 minutes and 24 seconds, and the shortest competition time is 29 minutes and 23 seconds. The competition lasted 29-34 minutes, and basically ended in about 30 minutes. In most cases, a tennis match usually takes 15 hours. In the professional tennis competition, the competition that ends in about half an hour basically does not appear, but according to the competition system of College Students' tennis competition in China, the time of College Students' tennis singles competition is generally short. Short competition time requires athletes to mobilize their physical functions as soon as possible in the shortest time, adapt to the rhythm of the competition faster and enter the competition state faster. At the beginning of the game, college tennis players should invest a high concentration, find and adapt to the characteristics of their opponents as soon as possible, mobilize various functions of their body, and make themselves occupy a favorable position in the game.

In Table 4, the confrontation time in the competition is between 8 minutes and 13 seconds and 11 minutes and 34 seconds, accounting for $27.96 \%-35.30 \%$ of the total competition time. The rest time of the game is between 19 minutes and 10 seconds and 23 minutes and 45 seconds. The confrontation time in the competition is short, accounting for almost one-third of the total competition time, while the rest time in the competition accounts for two-thirds of the total competition time. In college tennis competition, athletes have enough rest time.

\section{TABLE IV. Competition time and rest time}

\begin{tabular}{|c|c|c|c|c|c|}
\hline \multirow[b]{2}{*}{ МАТСН } & \multirow[b]{2}{*}{$\begin{array}{c}\text { TOTAL } \\
\text { GAME TIME }\end{array}$} & \multicolumn{2}{|c|}{ CONFRONTATION TIME } & \multicolumn{2}{|c|}{ REST TIME } \\
\hline & & TIME & $\begin{array}{c}\text { PERCENTAG } \\
\text { E OF TOTAL } \\
\text { TIME }\end{array}$ & TIME & $\begin{array}{c}\text { PERCENTAG } \\
\text { E OF TOTAL } \\
\text { TIME }\end{array}$ \\
\hline ONE & $\begin{array}{l}33 \text { minutes } 17 \\
\text { seconds }\end{array}$ & $\begin{array}{l}9 \text { minutes } 32 \\
\text { seconds }\end{array}$ & $28.64 \%$ & $\begin{array}{l}23 \text { minutes } 45 \\
\text { seconds }\end{array}$ & $71.36 \%$ \\
\hline TWO & $\begin{array}{l}31 \text { minutes } 18 \\
\text { seconds }\end{array}$ & $\begin{array}{l}11 \text { minutes } 03 \\
\text { seconds }\end{array}$ & $35.30 \%$ & $\begin{array}{c}20 \text { minutes and } 15 \\
\text { seconds }\end{array}$ & $64.70 \%$ \\
\hline THREE & $\begin{array}{l}33 \text { minutes } 24 \\
\text { seconds }\end{array}$ & $\begin{array}{l}11 \text { minutes and } 12 \\
\text { seconds }\end{array}$ & $33.53 \%$ & $\begin{array}{c}22 \text { minutes and } 12 \\
\text { seconds }\end{array}$ & $66.47 \%$ \\
\hline FOUR & $\begin{array}{l}29 \text { minutes } 23 \\
\text { seconds }\end{array}$ & $\begin{array}{l}8 \text { minutes and } 13 \\
\text { seconds }\end{array}$ & $27.96 \%$ & $\begin{array}{c}19 \text { minutes and } 10 \\
\text { seconds }\end{array}$ & $65.23 \%$ \\
\hline FIVE & $\begin{array}{l}33 \text { minutes } 07 \\
\text { seconds }\end{array}$ & $\begin{array}{c}11 \text { minutes } 34 \\
\text { seconds }\end{array}$ & $34.93 \%$ & $\begin{array}{c}21 \text { seconds } 33 \\
\text { seconds }\end{array}$ & $65.07 \%$ \\
\hline $\begin{array}{l}\text { AVERAG } \\
\text { E VALUE }\end{array}$ & $\begin{array}{l}32 \text { minutes } 04 \\
\text { seconds }\end{array}$ & $\begin{array}{l}10 \text { minutes } 18 \\
\text { seconds }\end{array}$ & & $\begin{array}{l}21 \text { minutes } 23 \\
\text { seconds }\end{array}$ & \\
\hline
\end{tabular}

Cardiovascular function plays an important role in sports, and the evaluation of its function is also the focus of sports human science research. There are many methods to measure human heart rate, including pulse rate finger touch method, heart sound auscultation method and heart rate remote measurement method. Heart rate is the frequency of periodic mechanical activity of 
Article History: Received: 28 October 2021 Revised: 05 December 2021 Accepted: 10 January 2022 Publication: 28 February 2022

the heart. The quiet heart rate of ordinary people is about $60-100$ beats / min. The heart rate is different in different age, sex and physiological conditions. Athletes' quiet heart rate is generally lower than ordinary people. Heart rate is a simple and easy test index to evaluate the intensity of exercise load. In a general range, there is a linear relationship between heart rate and exercise intensity. When exercising, athletes can choose to use the heart rate range according to their actual situation as their exercise basis. Because tennis players need to move in a large range and for a long time, and there are complex technical changes, it is more appropriate to use the heart rate index in the physiological index to evaluate. It can well reflect the physical load state of athletes at different time points in the competition, so the heart rate in the competition can clearly reflect the load borne by athletes in the competition and the characteristics of energy supply in the competition.

Creatine kinase is a kind of enzyme in the body. The activity of the enzyme directly affects the speed of enzymatic reaction, thus affecting the energy supply during exercise. The increase of energy required during exercise leads to the increase of many enzyme activities of material and energy metabolism in the body. Creatine kinase is a key enzyme in skeletal muscle energy metabolism. The activity of serum creatine kinase is closely related to exercise time, exercise intensity and exercise mode. Mild to moderate exercise has no significant effect on the activity of creatine kinase. Only when exercise reaches a certain intensity can it cause significant changes in creatine kinase. In the study of exercise physiology and biochemistry, creatine kinase is one of the sensitive indexes to evaluate the load. When the intensity of exercise load and the amount of exercise load are large, especially when the amount of exercise load is large. The permeability of muscle cell membrane will increase, resulting in the increase of creatine kinase content in blood.

Blood urea is the main index to evaluate the amount of exercise. Using blood urea as the evaluation index of tennis singles competition is to determine the changes of blood urea of college tennis players after the competition, so as to understand the metabolism of protein and amino acids in college tennis players during the tennis competition, so as to understand the amount of exercise of college tennis players during the competition. During exercise, a series of changes will occur in human function, such as accelerated metabolic process, increased metabolites and changes in renal function. These changes can be expressed through the changes of physical and chemical properties of urine. Therefore, through the physical and chemical properties of urine, we can judge the impact of exercise on renal function and objectively evaluate exercise load and physical state. There are many factors affecting urinary protein excretion, such as body function, exercise intensity, training methods and environment. There are great individual differences in urinary protein, so it is more suitable for individual comparison before and after exercise. The protein content in normal urine is very small, generally less than $15 \mathrm{mg}$. But after intense exercise, the protein in urine will increase suddenly. Therefore, urinary protein is an index to evaluate load intensity. 


\section{CONCLUSION}

In tennis training, college tennis players should strengthen the training of quickly mobilizing physical functions and improve their attention as soon as possible. Therefore, it is particularly important to warm up before the game. It's not just about mobilizing the body functions of tennis players. More importantly, make yourself enter the state of the game faster. It is suggested that during the warm-up, you can join the simulation competition practice, or have a short competition with your partner first.

Tennis competition is a sport with high physical fitness and self-regulation ability. Only by using a variety of means in daily training, can we show the athletes' due technical level in the face of the complex situation of the competition.

Through the research on College Students' tennis singles competition, the high load intensity is an important aspect of the competition. Therefore, in ordinary training, we should pay more attention to the training load intensity of college tennis players. Make the training close to the competition or slightly exceed the sports load of the competition. Better serve the competition.

\section{REFERENCES}

[1]Deng Yunlong. Basic Idea of "rhythm Alternation Theory" in Sports Training. Journal of Shenyang Institute of Physical Education, 2007 (03): 7-11

[2]Tian Maijiu. New Development of Theoretical System of Sports Training in China. Journal of Beijing Sport University (2): 145-148

[3]Tian Ye, Wang Qing, Feng Lianshi. Scientific Monitoring and Adjustment of Competitive State of Elite Athletes. Sports Science, 2008, 28 (009): 3-11

[4]Zhang Aifang, Feng Weiquan. Effects of Chinese Herbal Medicine on Some Biochemical Indexes of Exercise Training Mice. Journal of Beijing Sport University, 2010 (03): 70-81

[5]Zhan Jianguo. Development Status of Russian Competitive Sports and Experience and Enlightenment of Sports Training. Journal of Beijing Sport University, 2004 (06): 840-842

[6]Chen Xiaoping. on Special Characteristics -- the Main Problems and Countermeasures of Current Sports Training in China. Sports Science, 2007, 027 (002): 72-78

[7]Xu Benli. from Special Theory to Sports Training Science -- on the Formation and Development Trend of Sports Training Scientific Theory. Journal of Beijing Sport University, 2004 (06): 721-726

[8]Cao Jingwei, Yuan Shoulong, Xi Yi. Zhongguoliu in the Theoretical Research of Sports Training. Sports Science, 2004, 024 (002): 29-32

[9]Lu Changfen, Wang Jian. the Reform of the Curriculum System of Sports Training in China from the Perspective of Curriculum Reform of American Sports Colleges and Departments. Journal of Xi'an Institute of Physical Education, 2003, 20 (001): 96-100 
Forest Chemicals Review

www.forestchemicalsreview.com

ISSN: 1520-0191

January-February 2022 Page No.62-69

Article History: Received: 28 October 2021 Revised: 05 December 2021 Accepted: 10 January 2022 Publication: 28 February 2022

[10]Zhan Jianguo, Chai Guorong, Yang Wenwen. from the Perspective of the 27th Olympic Games, the Strength Pattern of International Athletics and the Direction of China's Track and Field Training. Journal of Beijing Sport University, 2000, 023 (004): 540-543 